\title{
Use of Radiographs for Movement Analysis of the Corn Wireworm, Melanotus communis (Coleoptera: Elateridae)
}

\author{
M. G. VILLANI ${ }^{1}$ AND F. GOULD \\ Department of Entomology, North Carolina State University, \\ Raleigh, North Carolina 27695
}

\begin{abstract}
Environ. Entomol. 15: 462-464 (1986)
ABSTRACT A laboratory technique is described in which "soft" radiographs are used to study wireworm, Melanotus communis Gyllenhal, movement patterns within a soil matrix. Advantages of this technique as compared with destructive sampling are discussed and examples of several possible applications are given.
\end{abstract}

DETAILED STUdies on the movement of soil insects have been largely ignored by population biologists. There is a general perception that such research, if not impossible, is difficult, tedious, and cost-ineffective when compared with similar studies of aboveground insects. Historically, agricultural entomologists have also shied away from this area of study although a number of studies on the movement of wireworms have been conducted in an effort to control members of this economically important soil insect family.

R. L. Rabb (personal communication) noted that: the greatest problem with studies of soil insects is not logistics, but rather with the alteration of the system through its study. Laboratory studies of movement and feeding were often done outside the soil (Fulton 1928), or between thin sandwiches of glass plates and sterile, homogeneous sand (Doane et al. 1975), which makes 3-D movement. by wireworms impossible. Radioactive tagging of wireworms with strong $\gamma$ emitters such as ${ }^{60} \mathrm{CO}$ (Arnason et al. 1950, Fuller et al. 1950, Fredericksen and Lilly 1955) proved hazardous to the insects and too imprecise for monitoring burrow formation accurately. In some cases, feeding behavior research involved destructive sampling of the soi] matrix (Kring 1955, Keaster et al. 1975), which may have resulted in alteration of the wireworm's typical behavior. Other studies of feeding focused on the results, rather than the process of feeding (i.e., feeding damage) (Stone 1935).

In an effort to gain a more realistic picture of the events that occur within the soil matrix, we have adapted an $x$-ray technique that had been used to study seed insects, parasitized cocoons, and wood-boring insects in their gallleries (see references in Yates and Belcher 1968) for the study of corn wireworm, Melanotus communis Gyllenhal, movement and feeding behavior. (For a detailed example in which this technique has been used to

' Current address: Dep. of Entomology, NYSAES, Cornell Univ., Geneva, NY 14456. monitor behavior and response of wireworms to natural antifeedants, see Villani and Gould 1985.)

\section{Materials and Methods}

The majority of the experiments were run in soil-filled (soil moisture $6+2 \%$ ) plexiglass chambers ( 30 by 15 by $4 \mathrm{~cm}$ ). These dimensions allowed the wireworms to move freely in all directions until the constraints of the chamber walls were met. Readable radiographs in chambers up to 43 by 36 by $10 \mathrm{~cm}$ were obtained, but as the thickness of a sample to be radiographed was increased, there was a corresponding increase in radiographic distortion. Some studies were done in smaller chambers such as bacterial culture tubes.

Wireworms used in this study ranged in length from 2 to $3 \mathrm{~cm}$. Tiny lead foil chips (ca. $1 \mathrm{~mm}$ diam) were fixed to the ninth abdominal segment by coating the dorsal plate of the segment with a thin layer of clear nail polish, placing the chip on the tacky plate, and then coating the chip and plate with two additional layers of nail polish. Care was taken not to cement the posterior abdominal segments together through the use of nail polish. (The individual wireworms were cooled to $6^{\circ} \mathrm{C}$ for several minutes to facilitate ease of handling for this procedure.) The chip, being the densest object in the soil matrix, stood out as a white dot in the radiograph. The soil appeared medium gray and the least dense, air-filled burrows appeared dark gray to black in the radiographs.

Radiographs were taken with an $x$-ray system (Faxitron $43805 \mathrm{~N}$ ) using a milliamperage (mA) of ca. 2.8 , and a kilovoltage $\left(\mathrm{kV}_{\mathrm{p}}\right)$ of ca. 80 . The length of exposure was automatically controlled (exposure time depended on the thickness of material, material density, moisture content, desired detail, film-to-focal point distance, and $\mathrm{kV}_{\mathrm{p}}$ ). The exposed $\mathrm{x}$-ray film was processed in a 190-liter developing tank (Bar-Ray Products, Brooklyn, N.Y.) with Kodak-X-Ray Fixer and Developer and hung to airdry. Finished radiographs were studied by view- 


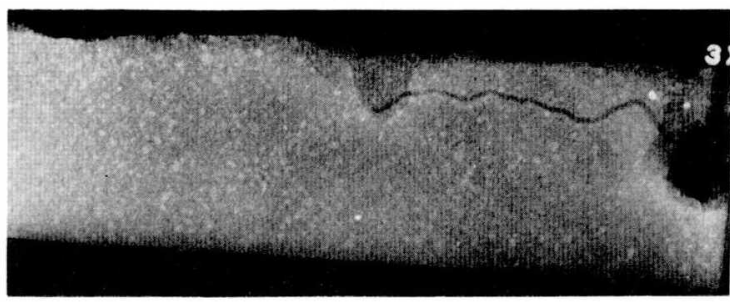

Fig. 1. Radiograph taken $2 \mathrm{~h}$ after the wireworm was placed in the middle of the chamber. The corn seed (dark area on right) was 4 days after germination. The apparent directed movement of the wireworm to the corn seed (dark line) is typical of active wireworms.

ing with backlighting or by photographing the backlighted radiograph and studying the enlarged, projected image.

Radiographs are shown in Fig. 1-5. In Fig. 14 , wireworms were released, head down, in the top center area of the arena ( 30 by 15 by $4 \mathrm{~cm}$ ). Each radiograph shown is one in a time series of radiographs taken of that arena over a 2-month period. Fig. 1 is representative of radiographs that indicate that wireworms have directed movement toward food. Fig. 2 demonstrates that wireworms can move quickly and freely through a noncompacted soil matrix. In Fig. 3, a lead chip placed on the wireworm is visible within the pupal cell. Although this radiograph was taken $\mathbf{4 5}$ days after introducing the wireworm to the arena, the wireworm never entered a feeding phase during that time and pupated early in that period. Fig. 4 represents our attempt to simulate wireworm response to a heterogeneously compacted soil or one with a plow layer. Wireworms tended to move along the compaction interface. Fig. 5 represents results of a test to determine wireworm response to a moisture gradient.

\section{Discussion}

This technique makes it possible to trace the burrow of wireworms within the soil matrix. It also shows physical properties of the soil matrix: particle size, extent of compaction, soil moisture, and heterogeneity (cracks, gaps, gravel, etc.). The lo-

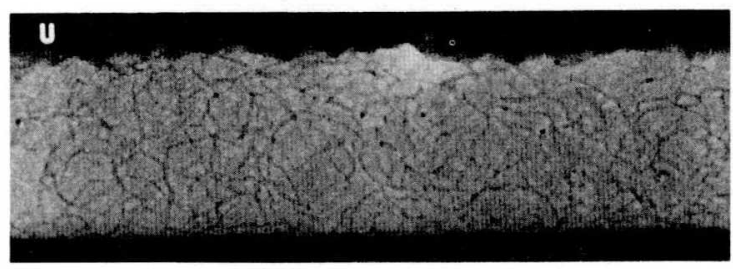

Fig. 2. Radiograph of chamber with wireworm without food, taken $12 \mathrm{~h}$ after placement. Note the complex matrix of tunnels that were apparently made during a search for food.

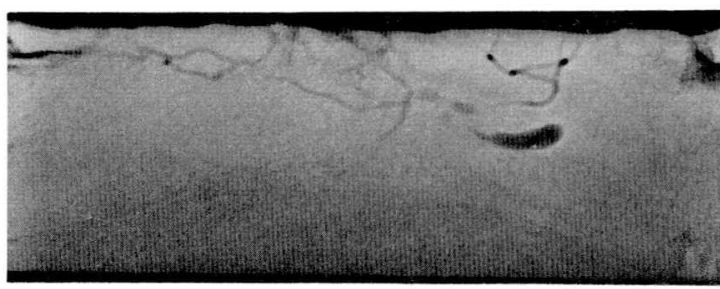

Fig. 3. Radiograph taken 45 days after wireworm placement. The burrows that are not oriented to the food bait are typical of prepupal movement patterns. The pupal cell, constructed over several days, is clearly visible in this radiograph. The triangular lead chip is visible within the cell.

cation and identity of target plants and food baits within the soil are easily noted with radiographs, and their condition and growth are often apparent. By attaching a tiny lead chip to the ninth abdominal segment of the wireworm, one can study both the patterns of the wireworm movement (burrows and pupal cells) and the location of the wireworm within its burrow network. Through the use of an irregularly shaped chip, the orientation of the wireworm in its burrow can be determined (unique shapes at the four compass points allow one to determine the wireworm's anterior-posterior and dorsal-ventral position in the test chamber). The movement of the wireworm after a molt, indicated by additional burrows and a stationary lead chip, can be used to assay pre- versus postmolting feeding behavior and movement patterns. There was no indication in our research that the use of "soft" radiographs adversely affected wireworm feeding or longevity when compared with those of insects not studied. Soft $\mathbf{x}$-rays are ca. 10 $\AA$ in wavelength, whereas in medicine, the wavelengths used range from 0.5 to $0.001 \AA$. These are known as "hard" $x$-rays. Soft $x$-rays have less energy and are more useful in investigating materials of a smaller size than is common in medicine. Specific effects of soft radiographs on the test subjects must be evaluated on a case-by-case basis. Studies over a number of generations in which genetic

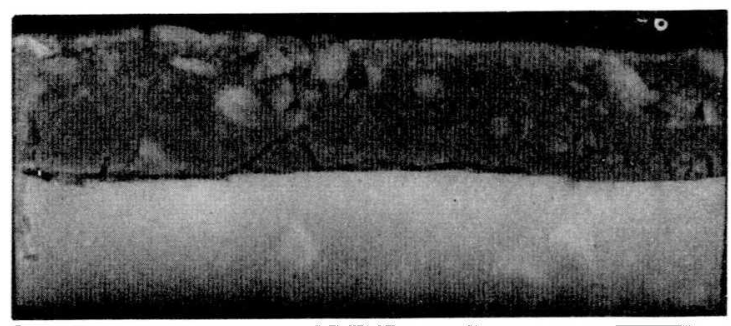

Fig. 4. Burrow pattern of a wireworm presented with a stratified soil is shown in this radiograph. The more compacted lower strata are more dense than the upper plow layer and show as a lighter shade of gray in the radiograph. Wireworm burrows at the soil interface are clearly visible. 


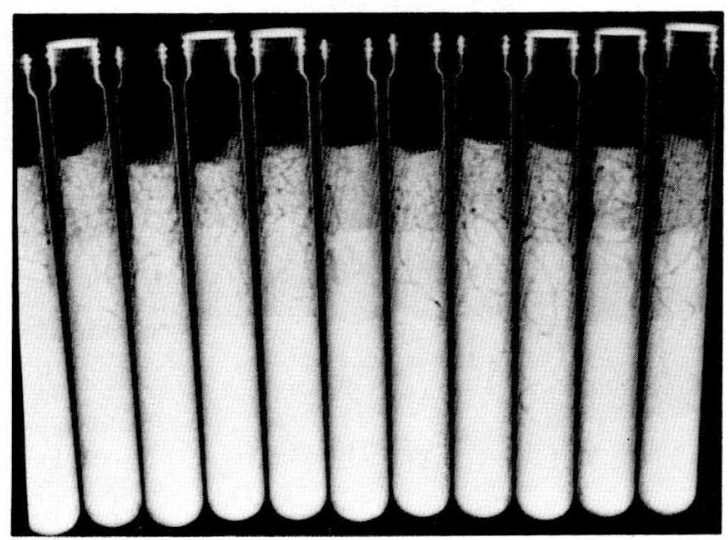

Fig. 5. Test tubes with moisture stratification. One wireworm placed in each tube.

changes would be critical must be carefully monitored when using any type of radiation source.

In conclusion, radiography is a technique that can be used to enhance the understanding of insect movement that occurs within the soil matrix. Used in conjunction with destructive techniques in the laboratory and in the field, both the process and result of soil insect behavior can be studied and analyzed.

We have outlined only one possible use of this technique as it applied to our research on corn wireworm feeding behavior. Clearly, adaptations of this procedure to facilitate its use with soil organisms of a variety of sizes and for experiments with diverse research objectives can be made through empirical modification of this technique.

\section{Acknowledgment}

This manuscript is Paper No. 9836 of the Journal Series of the N.C. Agric. Res. Serv., Raleigh.

\section{References Cited}

Arnason, A. P., R. A. Fuller, and J. W. T. Spinks. 1950. An electronic method of tracing the movements of soil-inhabiting insects. Science 3: 5-6.

Doane, J. F., Y. W. Lee, J. Klinger, and N. D. Westcott. 1975. The orientation response of Ctenicera destructor and other wireworms (Coleoptera: Elateridae) to germinating grain and to carbon dioxide. Can. Entomol. 107: 1233-1252.

Fredericksen, C. F., and J. H. Lilly. 1955. Measuring wireworm reactions to soil insecticides by tagging with radioactive cobalt. J. Econ. Entomol. 48: 438442.

Fuller, R. A., J. W. T. Spinks, A. P. Arnason, and H. McDonald. 1950. Use of radio-active tracers in investigations on soil-inhabiting insects, p. 715. In 81st Annual Report of the Entomological Society of Ontario.

Fulton, B. B. 1928. Some temperature relations of Melanotus (Coleoptera: Elateridae). J. Econ. Entomol. 21: 889-897.

Keaster, A. J., G. M. Chippendale, and B. A. Pill. 1975. Feeding behavior and growth of the wireworms Melanotus depressus and Limonius dubitans: effect of host plants, temperature, photoperiod, and artificial diets. Environ. Entomol. 4: 591-595.

Kring, J. B. 1955. A chamber for studies of siteselection by Elateridae. Entomol. News 61: 188-189.

Stone, M. W. 1935. Technique for life-history studies of wireworms. J. Econ. Entomol. 28: 817-824,

Villani, M. G., and F. Gould. 1985. Screening of crude plant extracts as feeding deterrents of the wireworm, Melanotus communis. Entomol. Exp. Appl. 37: 6975.

Yates, H., and E. Belcher. 1968. Tree Improvement and Nursery Management Branch, Southeastern Area of State and Private Forestry. In Proceedings, Southeast Forestry Radiography Workshop, January 9-11, 1968, Atlanta.

Received for publication 2 July 1984; accepted 30 December 1985. 